\title{
The Evi5 oncogene promotes laryngeal cancer cells proliferation by stabilizing c-Myc protein
}

\author{
Cheng-Gang Mao ${ }^{1 \dagger}$, Xiao-Chun Zhou ${ }^{1 \dagger}$, Yi-Dao Jiang ${ }^{1 *} \mathbb{C}$, Li-Jia Wan ${ }^{1}$, Ze-Zhang Tao ${ }^{2}$ and Jun Guo ${ }^{3^{*}}$
}

\begin{abstract}
Background: The Ecotropic viral integration site 5 (Evi5) is recognized as a potential oncogene and a cell cycle regulator. Evi5 regulates the abundance of Emi1, an inhibitor of the anaphase-promoting complex/cyclosome, to govern mitotic fidelity. Evi5 has been shown to be dysregulated in several cancer types. However, the expression and biological function of Evi5 in human laryngeal squamous cell carcinoma (LSCC) are still unknown.
\end{abstract}

Methods: Clustered regularly interspaced short palindromic repeats (CRISPR)-based gene editing was used to generate Evi5 knockout (KO) LSCC cells. The proliferation and cell cycle distribution of LSCC cells was determined. The effect of Evi5 on LSCC tumor growth in vivo was studied in a tumor xenograft model in mice. The interaction between Evi5 and c-Myc was detected by immunoprecipitation (IP) assay. Luciferase assay was used to determine the transcriptional activity of c-Myc.

Results: Here, we show that Evi5 controls LSCC tumorigenesis via the stabilization of C-MYC oncogene. CRISPR-mediated knockout (KO) of Evi5 decreased the proliferation and decreased colony formation ability of LSCC cells. Knockout of Evi5 caused increased G1 phase and decreased S phase cells. In the tumor-bearing nude mice, The transplanted tumors originated from Evi5-KO TU212 cells were significantly decreased when compared with control TU212 cells. At the molecular level, we found that Evi5 interacted with c-MYC and Evi5 antagonized E3 ligase FBXW7-mediated ubiquitination and degradation of c-Myc protein, and promoted c-Myc-dependent transactivation.

Conclusion: Given the critical role of c-Myc in tumorigenesis, our data suggest that Evi5 is a potential therapeutic target in LSCC, and inhibition of Evi5 should be a prospective strategy for LSCC therapy.

Keywords: Evi5, c-Myc, Laryngeal squamous cell carcinoma, Ubiquitination

*Correspondence: yidao_jiang@126.com; luowusheng@126.com

${ }^{\dagger}$ Cheng-Gang Mao and Xiao-Chun Zhou contributed equally to this work

${ }^{1}$ Department of Otolaryngology-Head and Neck Surgery, Jingzhou

Central Hospital, The Second Clinical Medical College, Yangtze University,

1 Ren-Min Road, Jingzhou 434020, People's Republic of China

${ }^{3}$ Department of Oncology, Affiliated Dongfeng Hospital, Hubei University

of Medicine, No. 10, Daling Road, Shiyan 442008, Hubei, People's Republic of China

Full list of author information is available at the end of the article

\section{Background}

Laryngeal carcinoma is the most common cancer in the larynx and the second most common malignant tumor of the respiratory system. The incidence of laryngeal cancer is generally low, accounting for $1-5 \%$ of all cancer sites, and in the United States, there were 13,430 new cases of laryngeal carcinoma and 3620 cancer deaths in 2016 [1]. Laryngeal squamous cell carcinoma (LSCC) is the major type for laryngeal carcinoma (about 95\%) [2]. Epidemiological investigations show that smoking is considered as the primary risk factor for laryngeal cancer and alcohol drinking is also an important pathogenic factor [3]. The

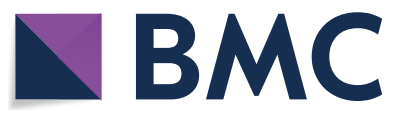

(c) The Author(s) 2020. This article is licensed under a Creative Commons Attribution 4.0 International License, which permits use, sharing, adaptation, distribution and reproduction in any medium or format, as long as you give appropriate credit to the original author(s) and the source, provide a link to the Creative Commons licence, and indicate if changes were made. The images or other third party material in this article are included in the article's Creative Commons licence, unless indicated otherwise in a credit line to the material. If material is not included in the article's Creative Commons licence and your intended use is not permitted by statutory regulation or exceeds the permitted use, you will need to obtain permission directly from the copyright holder. To view a copy of this licence, visit http://creativeco mmons.org/licenses/by/4.0/. The Creative Commons Public Domain Dedication waiver (http://creativecommons.org/publicdomain/ zero/1.0/) applies to the data made available in this article, unless otherwise stated in a credit line to the data. 
mechanism of smoking may be due to a large amount of carcinogen in tobacco smoke, trigging cellular DNA damage and eventually leading to carcinogenesis [4]. Genetic studies found that oncogene c-Myc is related to the event of laryngeal cancer [5]. c-Myc is a transcription factor containing a leukine zipper and regulates a large number of target genes [6]. Overexpression of c-Myc promotes cell growth, proliferation, apoptosis, transformation, premessenger-RNA splicing and genomic instability [7]. It has been reported that c-Myc is highly amplified in LSCC tissues, and the positive rate of c-Myc amplification and copy-number change increased with the increasing severity of laryngeal lesions [8]. MYCT1, previously named MTLC, is a novel candidate tumor suppressor gene and a direct downstream gene of c-Myc in LSCC. DNA methylation of MYCT1 altered the promoter activity by interfering with its binding to c-Myc in LSCC [9]. Overexpression of MYCT1 could inhibit cell proliferation and invasion and promote apoptosis in LSCC cells [10]. In spite of therapeutic advances, the 5-year survival rate for LSCC patients remains relatively low [1]. Thus, it is warranted to better understand the molecular mechanisms underlying LSCC tumorigenesis and to identify the novel therapeutic targets for LSCC treatment.

The human Evi5 gene was originally isolated in a patient with stage $4 \mathrm{~S}$ neuroblastoma with a constitutional chromosome translocation [11]. Evi5 belongs to a small subfamily of the Tre-2/Bub2/Cdc16 (TBC) domain-containing proteins, functions as a GTPase-activating protein for the Rab11 GTPase [12-14]. Evi5 is also required to allow the accumulation of the anaphase promoting complex, cyclosome (APC/C) inhibitor Emil in late G1. In the absence of Evi5, Emi1 is rapidly destructed in a Polo-like Kinase 1 (PLK1)- and $\beta$-transducin repeatcontaining protein $(\beta-\operatorname{TrCP})$-dependent manner, resulting in a failure to inactivate the $\mathrm{APC} / \mathrm{C}$, which in turn leads to a failure in $\mathrm{S}$ phase entry. Silencing of Evi5 caused increased centrosome number and a multinucleation phenotype, reflecting a failed cytokinesis event [15, 16]. The deregulated expression of Evi5 has also been observed in several kinds of cancers, indicating a tumor promoting function of Evi5 [17, 18]. However, whether Evi5 plays a role in LSCC is completely unknown.

In this study, we found that the Evi5 oncogene is an upstream regulator of c-Myc oncogene in LSCC. Evi5 antagonized FBXW7-mediated c-Myc destruction, leading to c-Myc accumulation and activation in LSCC.

\section{Materials and methods}

\section{Cell cultures and transfection}

Laryngeal cancer cell line TU212 cell line and HEK293T cells were purchased from the Shanghai Cell Collection (Shanghai, China). Cells were maintained in a humidified incubator at $37{ }^{\circ} \mathrm{C}$ with $5 \% \mathrm{CO}_{2}$, grown in RPMI 1640 or DMEM supplemented with $10 \%$ FBS (Hyclone, UT, USA) and $100 \mathrm{IU} / \mathrm{ml}$ penicillin/streptomycin. All cell lines used were negative for mycoplasma. All plasmids were purchased from Shanghai Genechem Co., LTD. Shanghai, China. For transfection, TU212 cells were cultured as described to $70-80 \%$ confluence in a 6-well plate. $1 \mu \mathrm{g}$ Flag-Evi5 and/or $1 \mu \mathrm{g}$ HA-FBXW7 plasmids were co-transfected using Lipofectamine 2000 (Thermo Fisher Scientific, USA.) following the manufacturer's instructions.

\section{CRISPR/Cas9 knock out (KO) cell lines}

TU212 cells were transfected with Evi5 $\mathrm{KO}$ plasmids (sc-407739, Santa Cruz Biotechnology, USA) using Lipofectamine 2000 (Thermo Fisher Scientific, USA) following the manufacturer's instructions. Cells were selected with $1 \mu \mathrm{g} / \mathrm{ml}$ puromycin over 1 week. Single clones were then selected and the knockout efficiency was verified by western blot assay.

\section{RNA isolation and real-time PCR}

Total RNA of tissues or cell lysates were extracted by using TRIzol reagent (Invitrogen, Shanghai). The cDNA was synthesized by using PrimeScript RT reagent Kit (TaKaRa, Dalian, China), quantitative real-time PCR was performed by using a SYBR Green Premix Ex Taq (TaKaRa) on Light Cycler480 (Roche, Switzerland). GAPDH was used for normalization of mRNAs expression. The PCR condition is first an initial holding period at $95{ }^{\circ} \mathrm{C}$ for $5 \mathrm{~min}$, followed by a two-step PCR program consisting of $95^{\circ} \mathrm{C}$ for $5 \mathrm{~s}$ and $60^{\circ} \mathrm{C}$ for 45 cycles. Relative quantitation analysis of gene expression results was performed according to the $2^{-\Delta \Delta \mathrm{Ct}}$ method [19]. The primers used were as follows: Cyclin D1, forward, 5'-GCTGCG AAGTGGAAACCATC-3'; reverse, 5'-CCTCCTTCT GCACACATTTGAA-3'. P21, forward, 5'-TGTCCGTCA GAACCCATGC-3'; reverse, 5'-AAGTCGAAGTTCCAT CGCTC-3'. Evi5, forward, 5'-AGAAACCCTAGTGGG AAACAGG-3'; reverse, 5'-TGACTGTATGCGATACTG TGTTC-3'. C-Myc, forward, 5'-GGCTCCTGGCAA AAGGTCA-3'; reverse, $5^{\prime}$-CTGCGTAGTTGTGCTGAT GT-3'.

GAPDH, forward 5'-GCACCGTCAAGGCTGAGA AC-3'; reverse 5'-TGGTGAAGACGCCAGTGGA-3' .

\section{Immunoprecipitation and TUBEs pulldown}

Cells were lysed in RIPA buffer to extract total cellular protein. Lysates were cleared by centrifugation $(12,000 \mathrm{~g}$ for $30 \mathrm{~min}$ at $4{ }^{\circ} \mathrm{C}$ ) and then filtered through $0.22 \mu \mathrm{M}$ spin filters to further remove cell debris. The resulting lysates were clarified by centrifugation at $15,000 \mathrm{~g}$ for $20 \mathrm{~min}$ at $4{ }^{\circ} \mathrm{C}$ before immunoprecipitation with antibodies and 
resin. Resin-containing immune complexes were washed 3 times with RIPA buffer washes and eluted with SDS loading buffer by boiling at $100{ }^{\circ} \mathrm{C}$ for $5 \mathrm{~min}$. The immune complexes were then subjected to western blot assay. Ubiquitin immunoprecipitation was performed under denaturing conditions. Lysates were harvested in RIPA buffer, followed by sonication Ubiquitinated substrates were precipitated from lysates using agarose-bound Tandem Ubiquitin Binding Entities (TUBEs, Life Sensors, UM401) following the manufacturer's protocol.

\section{Western blot analysis}

Cells were lysed in RIPA buffer to extract total cellular protein. Protein concentration was determined according to the BCA quantitative method, and $30 \mu \mathrm{g}$ of each protein sample was resolved by SDS-PAGE and the protein bands were transferred to a nitrocellulose membrane. Following protein transfer, the membrane was blocked for $1 \mathrm{~h}$ in the presence of $5 \%$ skimmed milk proteins, following by incubation at $4{ }^{\circ} \mathrm{C}$ overnight with the primary antibodies targeted against Evi5, EMI1, c-Myc, cyclin D1 and p21 (Abcam, Cambridge, USA), Flag, HA and GAPDH (Sigma-Aldrich, St. Louis, MO, USA). On the following day, the blots were incubated with a secondary antibody (Sigma-Aldrich, St. Louis, MO, USA) at room temperature for $1 \mathrm{~h}$, and specific protein bands were visualized by an enhanced chemiluminescence (ECL) assay kit (Pierce Biotechnology, Inc., Rockford, IL, USA).

\section{Cycloheximide inhibition test}

$5 \times 10^{5}$ cells were cultured to $70-80 \%$ confluence in a 6-well plate and treated with $20 \mu \mathrm{g} / \mathrm{ml}$ cycloheximide (CHX; Sigma-Aldrich; Merck KGaA) for 0, 2, 4 or $8 \mathrm{~h}$ and. c-Myc protein expression was measured by western blot, using GAPDH as loading control.

\section{FACS assay}

Cells were harvested and fixed by $70 \%$ ice-cold ethanol for $1 \mathrm{~h}$ and then incubated with propidium iodide (PI) (Beyotime, Shanghai, China) in the presence of $0.2 \mathrm{mg} /$ $\mathrm{ml}$ RNase A (Beyotime, Shanghai, China) for $15 \mathrm{~min}$, at $37{ }^{\circ} \mathrm{C}$. DNA content was measured on flow cytometry (Beckman, CA, USA).

\section{Colony formation assay}

Cells were seeded into 6 -well plates $\left(5 \times 10^{3}\right.$ cells per well). Cells were then cultured in the in complete media for 1-2 weeks. Cells were fixed with methanol (1\%) and formaldehyde (1\%), stained with $0.5 \%$ crystal violet. All experiments were performed at least three times. Representative experiments are shown.

\section{Luciferase reporter assays}

To monitor the transfection activity of c-Myc, a c-Mycdependent luciferase reporter plasmid $(\mathrm{p} 4 \times \mathrm{E}$-SVP-Luc) was used. The $\mathrm{p} 4 \times \mathrm{E}$-SVP-Luc and the $\mathrm{pRL}-\mathrm{TK}$ plasmid encoding Renilla luciferase were co-transfected with other plasmids into 293T cells for $48 \mathrm{~h}$. Luciferase activity was measured using the Dual Luciferase Reporter Assay System. Results are expressed relative to the activity in vector control.

\section{Xenograft assays}

Animal study was approved by Animal Care and Use Committee of Jing Zhou Central Hospital, the Second Clinical Medical College, Yangtze University, Jing Zhou, Hubei, China. Eight-week-old male nude mice were kept in a specific pathogen-free facility. Cells at a density of $1 \times 10^{7}$ were suspended in $50 \mu \mathrm{l}$ of DMEM medium, mixed with Matrigel (Corning; 1:1) and injected into the flanks of male nude mice. Tumor sizes were measured by a caliper and volumes were calculated using the formula length $\times$ width $2 \times 1 / 2$. Tumor weights were measured after mice were sacrificed.

\section{Statistical analysis}

All statistical analyses were assessed by the SPSS statistical software package, version 16.0 for Microsoft Windows (SPSS Inc., Chicago, IL, USA). Results are expressed as mean \pm standard deviation (SD). The unpaired twotailed $\mathrm{T}$ test was used for the comparison of parameters between two groups. Statistical significance is displayed as ${ }^{*} \mathrm{p}<0.05,{ }^{* *} \mathrm{p}<0.01$ or ${ }^{* * *} \mathrm{p}<0.001$.

\section{Results}

Evi5 is required for LSCC cells proliferation both in vitro and in vivo

To investigate whether Evi5 affects the proliferation of LSCC cells, we silenced the expression of Evi5 in LSCC TU212 cells used two small hairpin RNA (shRNA) against different regions of Evi5. Both shRNA achieved similar knockdown effect of Evi5, as evidenced by western blot (Fig. 1a). ShRNA-mediated depletion of Evi5 led to decreased growth rate (Fig. 1b) and deceased colony formation ability of TU212 cells (Fig. 1c). To further avoid the off-target of shRNA, we employed CRISPR/ Cas9 assay to generate Evi5 KO (knock out) TU212 cells (Fig. 1d). As expected, we found that, without Evi5, TU212 cells exhibited a significant growth retarded phenotype, including deceased proliferation and impaired colony formation ability (Fig. 1e, f). Moreover, knockout of Evi5 also caused increased G1 phase and decreased $S$ phase cells determined by flow cytometry (Fig. 1g). Finally, TU212 cells with or without Evi5 were injected 


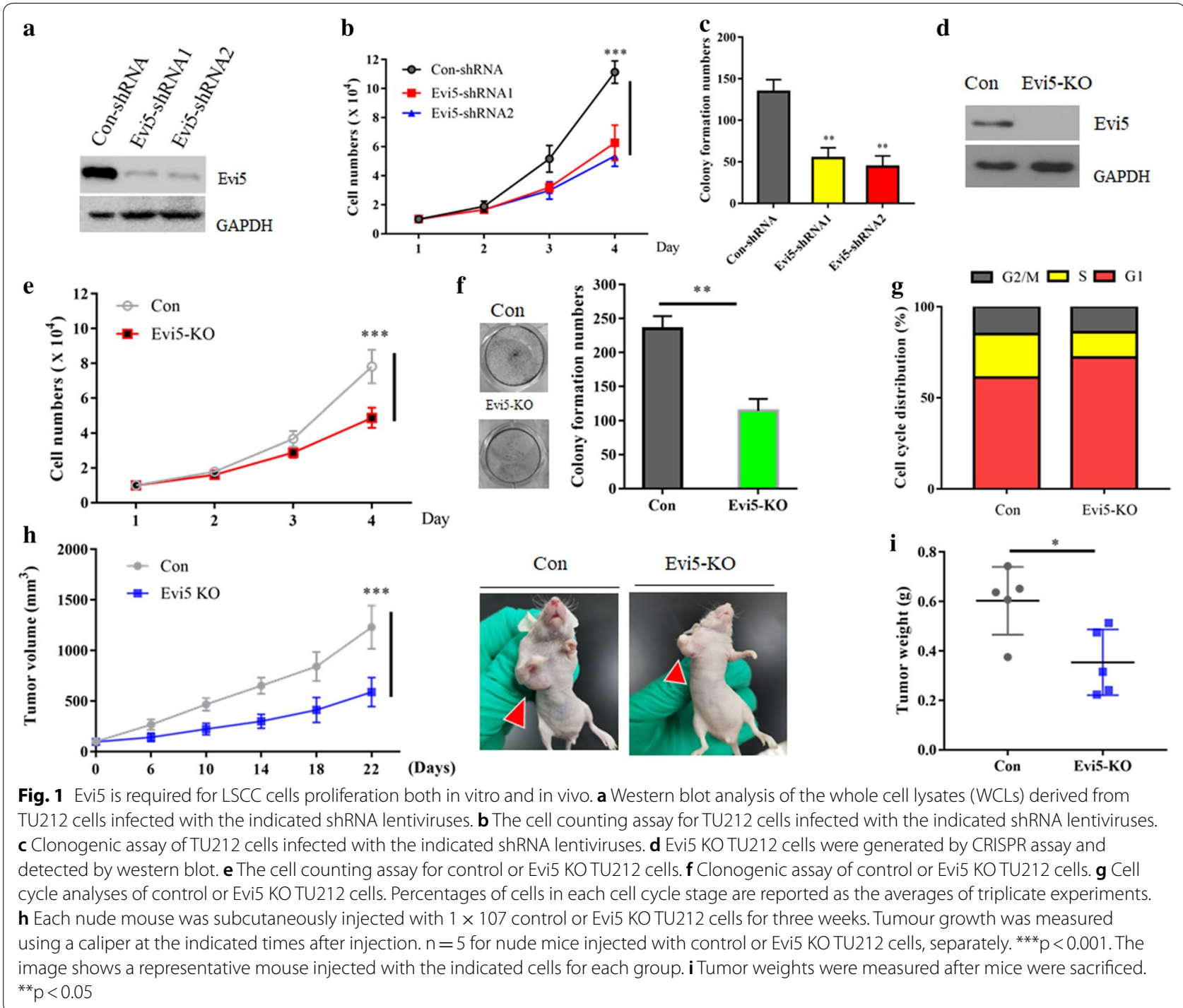

subcutaneously into the flanks of male nude mice. The transplanted tumors originated from Evi5-knockout TU212 cells were significantly decreased when compared with control TU212 cells, as revealed by measuring tumour mass (Fig. 1h, i). Together, these data suggested that Evi5 plays an oncogenic role in LSCC.

\section{Evi5 regulated the stability of c-Myc}

To investigate the underlining molecular mechanisms, we screened the protein expressions of several key signaling players by western blot. Agreed with previous studies, EMI1 was decreased in Evi5 KO cells, along with the decrement of p21, cyclin D1 and c-Myc protein (Fig. 2a). However, unlike p21 and cyclin D1, Evi5 has no obvious effects on c-Myc mRNA expression (Fig. 2b). Administration of proteasome inhibitor MG132 restored the expression of c-Myc in Evi5 KO cells (Fig. 2c). Moreover, ectopic expression of Evi5 increased the expression the c-Myc protein, but not it's mRNA (Fig. 2d, e). Importantly, we analyzed the expression of Evi5 and c-Myc in a small set of laryngeal cells and found that most cells exhibited a positive correlation between two proteins (Fig. 2f). Moreover, overexpression of Evi5 significantly increased the transcriptional activity of c-Myc (Fig. 2g). Thus, these data suggesting Evi5 regulates c-Myc protein stability.

\section{Evi5 interacts with c-myc to prevent its degradation}

To further test this possibility, we compared the halflife of c-Myc protein in TU212 cells with different Evi5 expression levels. We found that the half-life of c-Myc was prolonged in Evi5 overexpression cells but shorted 


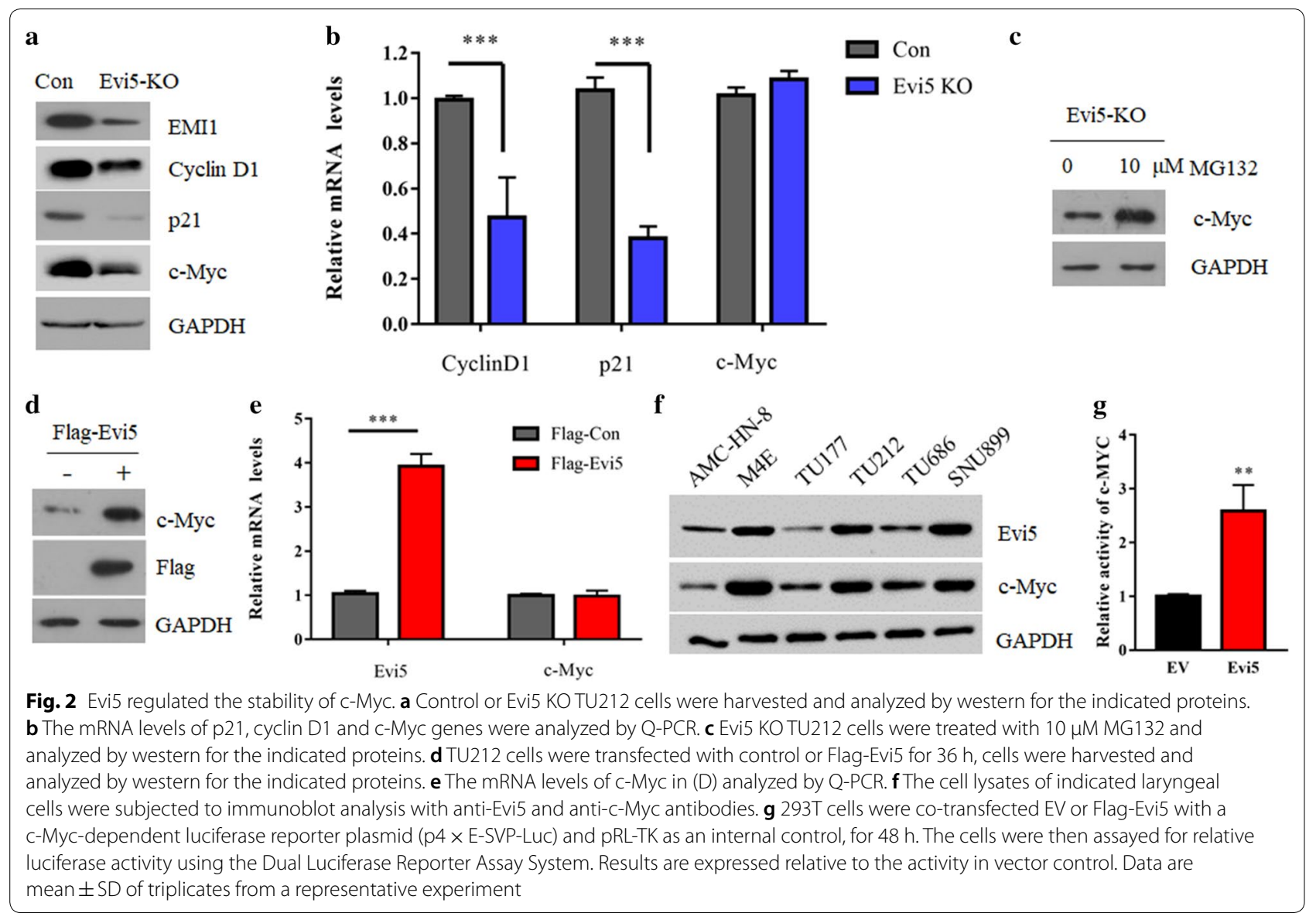

in Evi5 KO cells (Fig. 3a, b). Moreover, overexpression of Evi5 significantly decrease the ubiquitination form of c-Myc (Fig. 3c). Furthermore, c-Myc was readily detected in the Flag-Evi5 immunoprecipitate (Fig. 3d), suggesting a physical interaction between two proteins. Indeed, the endogenous interaction between Evi5 and c-Myc was clearly observed in TU212 cells (Fig. 3e, f). Taken together, these data indicate that Evi5 could prevent the ubiquitination and degradation of c-Myc protein by binding to c-Myc protein.

\section{Evi5 antagonizes FBXW7-mediated c-Myc ubiquitination and degradation}

It has been reported that c-Myc is an ubiquitination target of E3 ligase SCF FBXW7 [20, 21]. The e3 ligase activity of SCF complex required the Nedd8 modification of cullin1 [22]. Indeed, administration of MLN4924, is small inhibitor of NEDD8 activating enzyme [23], or overexpression of a DN-Cullin1 (dominant negative form of cullin1) restored the protein level of c-Myc in Evi5 KO cells (Fig. 4a, b), suggesting enhanced proteolysis of c-Myc in Evi5 KO cells by FBXW7. In consistent with it, silencing the expression of FBXW7 by shRNA also increased the protein level of c-Myc in Evi5 KO cells (Fig. 4c). We then asked whether Evi5 was able to prevent c-Myc binding to FBXW7. To this end, we co-expressed c-Myc and FBXW7 with or without Evi5 into 293T cells. We found that, in the present of Evi5, the interaction between c-Myc and FBXW7 was compromised (Fig. 4d). Thus, these data suggested that Evi5 antagonizes FBXW7-mediated c-Myc ubiquitination and degradation.

\section{Discussion}

The ubiquitin-proteasome pathway plays important roles in all cellular functions by regulating the abundance of regulatory proteins. The selectivity of ubiquitin-mediated degradation of substrate proteins is determined by the E3 ligases. Among the E3 ligase family, the CullinRING Ligases (CRLs) constitute the largest class of E3 ligases with more than 200 members [24]. Each of CRLs contains a different cullin subunit, which can be modified by the ubiquitin-like protein NEDD8, to activate CRLs for substrate ubiquitination [25]. This process can be inhibited by MLN4924, a small molecule inhibitor of NEDD8-activating enzymes that enhance CRL activity 


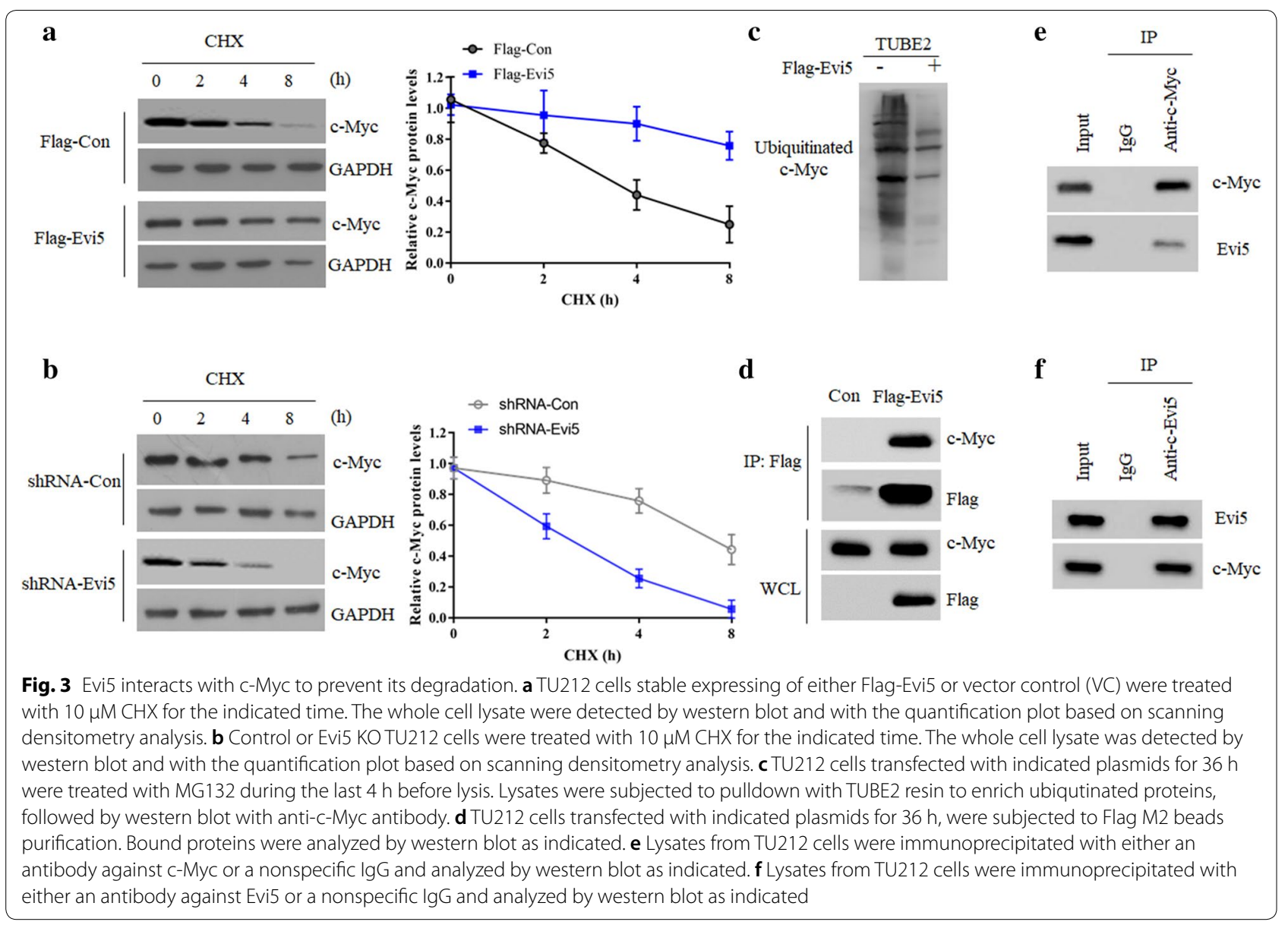

[23]. The CRL1 ligases, or SCF complexes, are the best characterized among all CRLs. SCF complex consists of the scaffolding protein Cullin 1, RBX1, SKP1 and one of $\sim 70$ various F-box proteins [26]. Given the relative large number of F-box proteins, only several members have been extensively investigated, including the oncogenic proteins $\beta$-TrCP, SKP2 and the tumor suppressor protein FBXW7 [27, 28]. c-Myc, a critical transcription factor and an well-known oncogene, was previously shown to be ubiquitinated and degraded by FBXW7 [21]. Given that the protein stability of c-Myc affected its transcriptional activity, characterization of the upstream regulators or mechanisms of c-Myc stability is important for understanding of c-Myc-dependent oncogenic process.

Evi5 belongs to a small subfamily of the Tre-2/Bub2/ Cdc16 (TBC) domain-containing proteins with diverse functions [14]. Evi5 undergoes several post-translational modifications including phosphorylation and ubiquitination, and has a dynamic association with mitotic structures during the $\mathrm{M}$ phase [15]. Evi5 has been identified as a regulator of cyclin accumulation via its effects on EMI1. Overexpression Emi1 is sufficient to drive $\mathrm{S}$ phase by stabilizing cyclin A protein [29], suggesting a promoting role of Evi5 in the regulation of cell proliferation. However, although Evi5 has been found to be overexpressed in certain cancer types, direct evidence for its role as an oncogene is still missing [12].

In the present study, we uncovered a novel oncogenic role of Evi5 in LSCC. By using shRNA-mediated gene knockdown or CRISPR-mediated gene knockout assay, we found inhibition of Evi5 in LSCC cells caused growth retard phenotype and delayed $\mathrm{S}$ phase entry which are coincidence with the decline of c-Myc protein. However, the mRNA level of c-Myc is unaltered, suggesting Evi5 might regulate c-Myc at posttranscriptional level. We further demonstrated that Evi5 positively regulated the stability of c-Myc protein by reducing its ubiquitination form, but Evi5 itself is not a deubiquitinase, suggesting it might not be a direct effect. Evi5 has been reported to be able to antagonize the binding between beta-Trcp and EMI1, and leading to the stabilizing of EMI1 [15]. We then asked whether this mechanism is also applicable in the regulation of c-Myc. We found that Evi5 could also antagonize the interaction between c-Myc and FBXW7. 


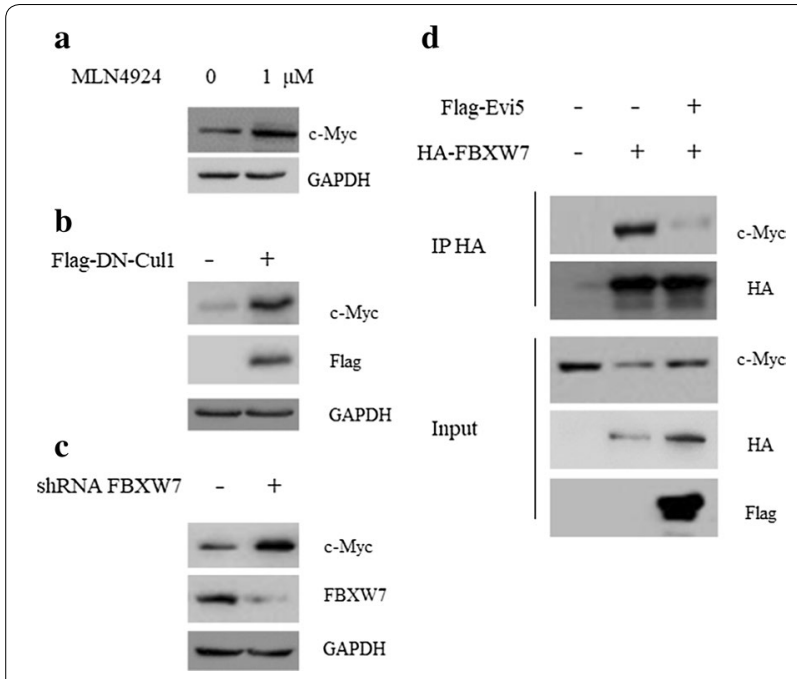

Fig. 4 Evi5 antagonizes FBXW7-mediated c-Myc ubiquitination and degradation. a Evi5 KO TU212 cells were treated with 1 MM MLN4924 and analyzed by western for the indicated proteins. b Evi5 KOTU212 cells were transfected with Flag-control or Flag-DN-Cul1 vectors for $36 \mathrm{~h}$, cells were harvested and analyzed by western for the indicated proteins. c Evi5 KO TU212 cells were transfected with control shRNA or shRNA against FBXW7 for $36 \mathrm{~h}$, cells were harvested and analyzed by western for the indicated proteins. d TU212 cells were transfected with indicated plasmids for $36 \mathrm{~h}$. Cells were harvested and lysates were immunoprecipitated with anti-HA antibody, and analyzed by western blot as indicated

Thus, we data clearly showed that Evi5 stabilized c-Myc by preventing the binding of FBXW7 to c-Myc. Considering the critical role of c-Myc in LSCC, Evi5 could also be an important player in the development of LSCC by modulating the stability of c-Myc. However, the exact roles of Evi5 in the development of LSCC should be further explored by using large clinic samples and in Evi5 KO mice.

In summary, our data demonstrate that the Evi5FBXW7-c-Myc regulatory axis serves a role in the regulation of LSCC cell proliferation in vitro and tumorigenesis in vivo. These findings suggest that Evi5 is a potential therapeutic target in LSCC, and inhibition of Evi5 is the prospective strategy for LSCC therapy.

\section{Conclusion}

Our study is the first to show that Evi5 is required for LSCC cells proliferation and tumorigenesis both in vitro and in vivo. Our finding further provides a novel molecular mechanism for the positive regulation of c-Myc by Evi5 in LSCC cells. Interference with this regulatory effect of Evi5 significantly inhibited LSCC cells proliferation. Thus, given the critical role of c-Myc in tumorigenesis, our data suggest that Evi5 is a potential therapeutic target in LSCC, and inhibition of Evi5 should be a prospective strategy for LSCC therapy.

\section{Abbreviations}

CHX: Cycloheximide; LSCC: Laryngeal squamous cell carcinoma; IP: Immunoprecipitation; shRNA: Small hairpin RNA; TBC:Tre-2/Bub2/Cdc16; TUBEs: Tandem ubiquitin binding entities.

\section{Acknowledgements}

Not applicable.

\section{Authors' contributions}

CM, JG and YJ collaborated to design the study. CM, XZ and LW were responsible for experiments. CM, LW and ZT analyzed the data. CM and JG wrote the paper. All authors collaborated to interpret results and develop the manuscript. All authors read and approved the final manuscript.

\section{Funding}

This project is funded by the Science and Technology Program of Jingzhou City (nos. 2017038; 2017044).

\section{Availability of data and materials}

Please contact corresponding author for data requests.

\section{Ethics approval and consent to participate}

This study was approved by Animal Care and Use Committee of Jing Zhou Central Hospital, the Second Clinical Medical College, Yangtze University, Jing Zhou, Hubei, China.

\section{Consent for publication}

All listed authors have actively participated in the study and have read and approved the submitted manuscript.

\section{Competing interests}

The authors declare that they have no competing interests.

\section{Author details}

${ }_{1}^{1}$ Department of Otolaryngology-Head and Neck Surgery, Jingzhou Central Hospital, The Second Clinical Medical College, Yangtze University, 1 Ren-Min Road, Jingzhou 434020, People's Republic of China. ${ }^{2}$ Department of Otolaryngology-Head and Neck Surgery, Renmin Hospital of Wuhan University, Wuhan 430060, People's Republic of China. ${ }^{3}$ Department of Oncology, Affiliated Dongfeng Hospital, Hubei University of Medicine, No. 10, Daling Road, Shiyan 442008, Hubei, People's Republic of China.

Received: 28 November 2019 Accepted: 29 January 2020

Published online: 07 February 2020

\section{References}

1. Steuer CE, El-Deiry M, Parks JR, Higgins KA, Saba NF. An update on larynx cancer. CA. 2017;67(1):31-50.

2. Marioni G, Marchese-Ragona R, Cartei G, Marchese F, Staffieri A. Current opinion in diagnosis and treatment of laryngeal carcinoma. Cancer Treat Rev. 2006;32(7):504-15.

3. Zuo JJ, Tao ZZ, Chen C, Hu ZW, Xu YX, Zheng AY, Guo Y. Characteristics of cigarette smoking without alcohol consumption and laryngeal cancer: overall and time-risk relation. A meta-analysis of observational studies. Eur Arch Oto-rhino-laryngol. 2017;274(3):1617-31.

4. Szyfter K, Szmeja Z, Szyfter W, Hemminki K, Banaszewski J, Jaskula-Sztul $\mathrm{R}$, Louhelainen J. Molecular and cellular alterations in tobacco smokeassociated larynx cancer. Mutat Res. 1999;445(2):259-74.

5. Freier K, Joos S, Flechtenmacher C, Devens F, Benner A, Bosch FX, Lichter P, Hofele C. Tissue microarray analysis reveals site-specific prevalence of oncogene amplifications in head and neck squamous cell carcinoma. Cancer Res. 2003;63(6):1179-82.

6. Kress TR, Sabo A, Amati B. MYC: connecting selective transcriptional control to global RNA production. Nat Rev Cancer. 2015;15(10):593-607. 
7. Koh CM, Bezzi M, Low DH, Ang WX, Teo SX, Gay FP, Al-Haddawi M, Tan SY, Osato M, Sabo A, et al. MYC regulates the core pre-mRNA splicing machinery as an essential step in lymphomagenesis. Nature. 2015;523(7558):96-100.

8. Liu Y, Gong LP, Dong XL, Liu HG. Detection of C-MYC oncogene translocation and copy number change in the normal-dysplasia-carcinoma sequence of the larynx by fluorescence in situ hybridization. Diagn Cytopathol. 2013;41(6):515-9.

9. Yang M, LiW, Liu YY, Fu S, Qiu GB, Sun KL, Fu WN. Promoter hypermethylation-induced transcriptional down-regulation of the gene MYCT1 in laryngeal squamous cell carcinoma. BMC Cancer. 2012;12:219.

10. Fu S, Guo Y, Chen H, Xu ZM, Qiu GB, Zhong M, Sun KL, Fu WN. MYCT1-TV, a novel MYCT1 transcript, is regulated by C-Myc and may participate in laryngeal carcinogenesis. PLoS ONE. 2011;6(10):e25648.

11. Roberts T, Chernova O, Cowell JK. NB4S, a member of the TBC1 domain family of genes, is truncated as a result of a constitutional $t(1 ; 10)(p 22 ; q 21)$ chromosome translocation in a patient with stage $4 \mathrm{~S}$ neuroblastoma. Hum Mol Genet. 1998;7(7):1169-78.

12. Lim YS, Tang BL. The Evi5 family in cellular physiology and pathology. FEBS Lett. 2013:587(12):1703-10

13. Westlake CJ, Junutula JR, Simon GC, Pilli M, Prekeris R, Scheller RH, Jackson PK, Eldridge AG. Identification of Rab11 as a small GTPase binding protein for the Evi5 oncogene. Proc Natl Acad Sci USA. 2007;104(4):1236-41.

14. Dabbeekeh JT, Faitar SL, Dufresne CP, Cowell JK. The EVI5 TBC domain provides the GTPase-activating protein motif for RAB11. Oncogene. 2007;26(19):2804-8.

15. Eldridge AG, Loktev AV, Hansen DV, Verschuren EW, Reimann JD, Jackson PK. The evi5 oncogene regulates cyclin accumulation by stabilizing the anaphase-promoting complex inhibitor emi1. Cell. 2006;124(2):367-80.

16. Faitar SL, Sossey-Alaoui K, Ranalli TA, Cowell JK. EVI5 protein associates with the INCENP-aurora B kinase-survivin chromosomal passenger complex and is involved in the completion of cytokinesis. Exp Cell Res. 2006:312(12):2325-35.

17. Tang J, Ou J, Xu C, Yi C, Xue F, Xu L, Lai F, Tang J, Li S, Kang T, et al. EVI5 is a novel independent prognostic predictor in hepatocellular carcinoma after radical hepatectomy. Oncol Rep. 2017;38(4):2251-8.

18. Jacob B, Osato M, Yamashita N, Wang CQ, Taniuchi I, Littman DR, Asou N Ito Y. Stem cell exhaustion due to Runx1 deficiency is prevented by Evi5 activation in leukemogenesis. Blood. 2010;115(8):1610-20.
19. Livak KJ, Schmittgen TD. Analysis of relative gene expression data using real-time quantitative PCR and the 2(-Delta Delta $C(T)$ ) method. Methods (San Diego, Calif). 2001;25(4):402-8.

20. Yada M, Hatakeyama S, Kamura T, Nishiyama M, Tsunematsu R, Imaki H, Ishida N, Okumura F, Nakayama K, Nakayama KI. Phosphorylationdependent degradation of $\mathrm{c}-\mathrm{Myc}$ is mediated by the F-box protein Fbw7. EMBO J. 2004;23(10):2116-25.

21. Welcker M, Orian A, Jin J, Grim JE, Harper JW, Eisenman RN, Clurman $\mathrm{BE}$. The Fbw7 tumor suppressor regulates glycogen synthase kinase 3 phosphorylation-dependent c-Myc protein degradation. Proc Natl Acad Sci USA. 2004;101(24):9085-90.

22. Kawakami T, Chiba T, Suzuki T, Iwai K, Yamanaka K, Minato N, Suzuki H, Shimbara N, Hidaka Y, Osaka F, et al. NEDD8 recruits E2-ubiquitin to SCF E3 ligase. EMBO J. 2001;20(15):4003-12.

23. Soucy TA, Smith PG, Milhollen MA, Berger AJ, Gavin JM, Adhikari S, Brownell JE, Burke KE, Cardin DP, Critchley S, et al. An inhibitor of NEDD8-activating enzyme as a new approach to treat cancer. Nature. 2009;458(7239):732-6.

24. Zheng N, Shabek N. Ubiquitin ligases: structure, function, and regulation. Annu Rev Biochem. 2017:86:129-57.

25. Enchev Rl, Schulman BA, Peter M. Protein neddylation: beyond cullinRING ligases. Nat Rev Mol Cell Biol. 2015;16(1):30-44.

26. Wang Z, Liu P, Inuzuka H, Wei W. Roles of F-box proteins in cancer. Nat Rev Cancer. 2014;14(4):233-47.

27. Frescas D, Pagano M. Deregulated proteolysis by the F-box proteins SKP2 and beta-TrCP: tipping the scales of cancer. Nat Rev Cancer. 2008:8(6):438-49.

28. Welcker M, Clurman BE. FBW7 ubiquitin ligase: a tumour suppressor at the crossroads of cell division, growth and differentiation. Nat Rev Cancer. 2008;8(2):83-93.

29. Hsu JY, Reimann JD, Sorensen CS, Lukas J, Jackson PK. E2F-dependent accumulation of hEmi1 regulates $S$ phase entry by inhibiting APC(Cdh1). Nat Cell Biol. 2002;4(5):358-66.

\section{Publisher's Note}

Springer Nature remains neutral with regard to jurisdictional claims in published maps and institutional affiliations.
Ready to submit your research? Choose BMC and benefit from:

- fast, convenient online submission

- thorough peer review by experienced researchers in your field

- rapid publication on acceptance

- support for research data, including large and complex data types

- gold Open Access which fosters wider collaboration and increased citations

- maximum visibility for your research: over 100M website views per year

At BMC, research is always in progress.

Learn more biomedcentral.com/submissions 